\title{
Mineralogical and Technological Aspects of Phosphate Ore Processing
}

\author{
A. Elbendari ${ }^{(凶)}$, V. Potemkin, T. Aleksandrova, and N. Nikolaeva \\ Mineral Processing Department, Saint Petersburg Mining University, \\ Saint Petersburg, Russia \\ abdullah_elbendary@yahoo.com
}

\begin{abstract}
The article studies the mineralogical features of phosphate ores. In the conditions of declining industrial reserves of apatite-containing ores, issues of a more comprehensive and in-depth study of the mineral and material composition, as well as the improvement of existing technologies for the processing of this type of raw material, become topical. Using optical methods of analysis, electron microscopy with automated mineralogical analysis (MLA), mineral and elemental composition of apatite was obtained. Taking into account the studied mineralogical and material composition, experiments on grinding and flotation were carried out. Based on these data, it was concluded that the optimal scheme for the processing of phosphate ores is a flotation scheme with preliminary selective disintegration.
\end{abstract}

Keywords: Mineralogical composition $\cdot$ Grinding $\cdot$ Beneficiation · Phosphorus-bearing minerals

\section{Introduction}

Phosphates are one of the most important minerals on Earth, as they are used as fertilizers for agriculture and as a necessary raw material for the chemical industry (Brylyakov 2004; Abouzeid 2007). In addition, phosphates are the source of rare-earth elements. They are used in many commercial and industrial products, such as: detergents, toothpastes and fireproof materials. Worldwide consumption of $\mathrm{P}_{2} \mathrm{O}_{5}$ in all of the areas above is projected to grow gradually from 44.5 million tons in 2016 to 48.9 million tons in 2020 (Jasinski 2017).

In the conditions of declining industrial high-quality reserves of phosphoruscontaining ores, issues of a more comprehensive and in-depth study of the mineral and material composition, as well as improvement of existing technologies for processing this type of raw material, become urgent. The study of the influence of the mineral raw materials composition on the features of the beneficiation schemes construction is given in the works of many authors (Aleksandrova et al. 2012; Evdokimova et al. 2012; Gerasimova et al. 2018; Litvintsev et al. 2006; Mitrofanova et al. 2017). 


\section{Methods and Approaches}

The object of the study was apatite-nepheline ore of the Khibiny deposits group (Russia) and phosphate ore of the Abu-Tartur deposit (Egypt). For the development of beneficiation schemes and modes, complex studies were carried out on mineral and elemental composition, including optical methods of analysis, electron microscopy using automated mineralogical analysis (MLA), etc. As a result of the work, the mineral composition of apatite-nepheline ore (ANO) and phosphate ore (PO) was studied taking into account the data of optical and electron microscopic studies, spot Xray spectral and chemical analyzes, atomic emission spectrometry, automated mineralogical analysis. The chemical composition of ANO and PO is given in the Table 1.

Table 1. The chemical composition of ANO and PO

\begin{tabular}{l|c|l|c}
\hline $\begin{array}{l}\text { Apatite-nephelineores } \\
\text { (Russia) }\end{array}$ & \multicolumn{2}{l}{ Phosphoriteore (Egypt) } \\
\hline Component & Content, \% & Component & Content, \% \\
\hline $\mathrm{SiO}_{2}$ & 32.50 & $\mathrm{SiO}_{2}$ & 19.4 \\
\hline $\mathrm{TiO}_{2}$ & 2.20 & $\mathrm{TiO}_{2}$ & 0.06 \\
\hline $\mathrm{Al}_{2} \mathrm{O}_{3}$ & 15.52 & $\mathrm{Al}_{2} \mathrm{O}_{3}$ & 2.6 \\
\hline $\mathrm{Fe}$ & 5.45 & $\mathrm{Fe}$ & 5.3 \\
\hline $\mathrm{CaO}$ & 18.28 & $\mathrm{CaO}$ & 37.6 \\
\hline $\mathrm{MgO}$ & 0.92 & $\mathrm{MgO}$ & 0.8 \\
\hline $\mathrm{MnO}$ & 0.16 & $\mathrm{MnO}$ & 0.05 \\
\hline $\mathrm{K}_{2} \mathrm{O}$ & 4.20 & $\mathrm{~K}_{2} \mathrm{O}$ & 0.59 \\
\hline $\mathrm{Na}_{2} \mathrm{O}$ & 5.56 & $\mathrm{Na}_{2} \mathrm{O}$ & 0.57 \\
\hline $\mathrm{P}_{2} \mathrm{O}_{5}$ & 12.50 & $\mathrm{P}_{2} \mathrm{O}_{5}$ & 21.8 \\
\hline $\mathrm{SO}_{3}$ & 0.04 & $\mathrm{SO}_{3}$ & 1.6 \\
\hline $\mathrm{CO}_{2}$ & 0.05 & $\mathrm{CO}_{2}$ & 1.2 \\
\hline $\mathrm{LOI}^{\mathrm{TO}}$ & 2.62 & $\mathrm{LOI}$ & 8.43 \\
\hline $\mathrm{Total}$ & $\mathbf{1 0 0 . 0 0}$ & $\mathrm{Total}$ & $\mathbf{1 0 0 . 0 0}$ \\
\hline
\end{tabular}

To study the possibility of increasing efficiency of the flotation process, studies were carried out on the selection of the optimal grinding mode and a series of flotation experiments.

\section{Results and Discussion}

According to the mineralogical analysis, the main primary minerals of ANO are apatite and nepheline, the contents of which are respectively 30.67 and $30.88 \%$; minor quantities contain pyroxenes, mica, feldspars, as well as natrolite and kaolinite secondary minerals formed due to the destruction of the primary mineral phases. 
Phosphorus-containing minerals of the sample are apatite, eschynite, phosphates of rare-earth elements and lomonosovite, with a distribution to these minerals of 99.94 , $0.01,0.02$ and $0.03 \%$ phosphorus respectively. Valuable minerals of the sample are apatite - the main mineral concentrating phosphorus and nepheline - the main mineral concentrating aluminum.

Apatite is the main mineral concentrator of phosphorus in the ore; it forms disseminated prismatic crystals, vein clusters of crystals, less often massive clusters of fractured xenomorphic grains, often included in the grains of other minerals - pyroxenes, mica, sphene, nepheline (Fig. 1).

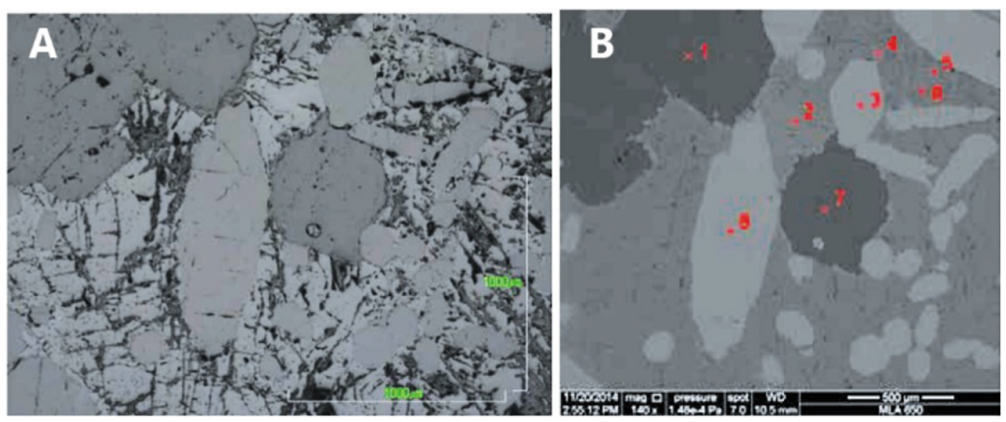

Fig. 1. Apatite crystals in the aegirine-augite matrix. Spectra in (b): 1,7 - nepheline; 2, 4 aegirine-augit; 3, 8 - apatite; 5, 6 - arfvedsonit

Image: (a) - in reflected light; (b) - in backscattered electrons. Apatite is characterized by a pronounced idiomorphism of grains that have clear crystallographic outlines; the shape of apatite grains is columnar, prismatic, acicular, which causes a weak connection between them in aggregates. The crystalline form of apatite, the natural brittleness of the mineral will contribute to the primary destruction of the mineral during ore grinding and the concentration of apatite in smaller grades.

According to MLA data, $32.78 \%$ of the mineral in ore is distributed into free particles, $22.29 \%$ into binary and $44.92 \%$ into polymineral intergrowth.

Phosphate minerals in PO are represented by carbonate-fluoroapatite, fluoroapatite, hydroxylapatite, and francolite. The most common clay minerals in the studied sediments are smectites. The amount of kaolinite and illite in general is insignificant, although their content is also high enough. Among the non-phosphate components of the PO, detrital quartz, as well as ankerite and pyrite cement in unaltered phosphates, are predominant. Pyrite and ankerite in many cases replace partially or completely phosphate grains. Elements such as $\mathrm{Ba}, \mathrm{Cr}, \mathrm{Ni}, \mathrm{Sr}, \mathrm{Y}$, and $\mathrm{Zr}$ are found in relatively high concentrations, while $\mathrm{Co}, \mathrm{Nb}, \mathrm{Pb}, \mathrm{Rb}$, Th, and $\mathrm{U}$ are found in relatively low concentrations (Abdel-Moghny and Zhabin 2011; Baioumy 2013) (Fig. 2). 

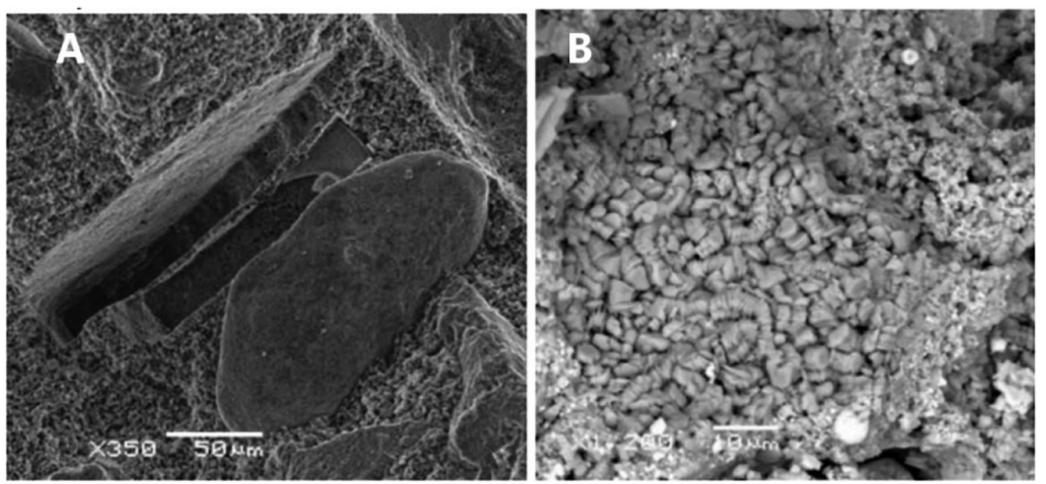

Fig. 2. Electron microscopic images of PO (Baioumy 2013). (a) - rounded silica inclusions; (b) - kaolinite plates

To determine the optimal processing scheme for ANO and PO, samples with a grain size of less than $2 \mathrm{~mm}$ and a mass of $550 \mathrm{~g}$ were ground in a ball mill in accordance with the specifications given in Table 2:

Table 2. Mill characteristics and experiment conditions

\begin{tabular}{|c|c|c|c|c|c|c|c|c|}
\hline \multirow[t]{4}{*}{ Mill } & \multicolumn{4}{|c|}{ Inner diameter $(\mathrm{D}), \mathrm{mm}$} & \multicolumn{4}{|c|}{125} \\
\hline & \multicolumn{4}{|c|}{ Length, mm } & \multicolumn{4}{|c|}{170} \\
\hline & \multicolumn{4}{|c|}{ Volume, $\mathrm{cm}^{3}$} & \multicolumn{4}{|c|}{2085} \\
\hline & \multicolumn{4}{|c|}{ Critical speed, rpm } & \multicolumn{4}{|c|}{120} \\
\hline \multirow[t]{7}{*}{ Media (Balls) } & \multicolumn{4}{|c|}{ Material } & \multicolumn{4}{|c|}{ Alloy steel } \\
\hline & $\mathrm{d}, \mathrm{mm}$ & 19 & 22 & 25 & 27 & 28 & 29 & 30 \\
\hline & Number & 1 & 2 & 2 & 4 & 4 & 3 & 1 \\
\hline & $\mathrm{d}, \mathrm{mm}$ & 32 & 34 & 35 & 36 & 39 & 40 & 41 \\
\hline & Number & 2 & 1 & 2 & 1 & 1 & 2 & 1 \\
\hline & \multicolumn{4}{|c|}{ Specific gravity } & \multicolumn{4}{|l|}{7.8} \\
\hline & \multicolumn{4}{|c|}{ Mass of balls, $\mathrm{g}$} & \multicolumn{4}{|c|}{3388.5} \\
\hline \multirow[t]{3}{*}{ Material } & \multicolumn{8}{|c|}{ Igneous \& sedimentary phosphate ore } \\
\hline & \multicolumn{4}{|c|}{ Specific gravity } & \multicolumn{4}{|c|}{$3.1 \& 2.7$} \\
\hline & \multicolumn{4}{|c|}{ Powder weight, $g$} & \multicolumn{4}{|c|}{$550 \mathrm{gm}$} \\
\hline
\end{tabular}

The grinding results are shown in Fig. 3.

As a result of the grinding process study, it was found that with an increase in the grinding time, the particle size sharply decreases, and pulp grinding with a solid content of $50 \%$ gives the best results. Studies have also been conducted for the process of grinding apatite ore with the addition of tributyl phosphate in amount of 500 and 


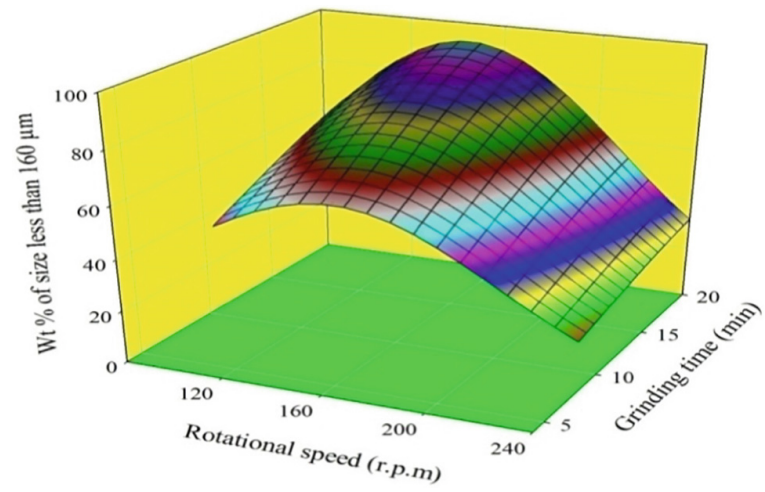

Fig. 3. 3D relationship between the rotational speed and grinding time

$1000 \mathrm{ml} /$ ton. Studies have shown that the addition of surface-active substances (tributyl phosphate) during grinding of ANO and PO does not only increase the efficiency of grinding, but also partially convert rare-earth metals into soluble form with their subsequent extraction.

Beneficiation of ANO and PO samples was carried out according to the flowchart shown in Fig. 4.

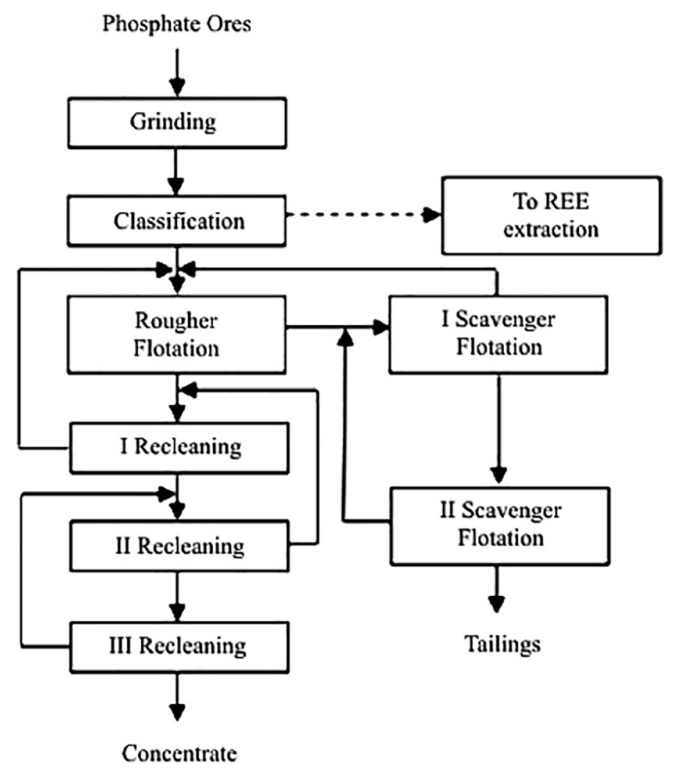

Fig. 4. Block diagram of phosphate ore beneficiation 
Based on the studies, it was found that this scheme is optimal for both samples (sedimentary and volcanic).

\section{Conclusions}

In the conditions of declining quality of industrial reserves of phosphate ores, issues of a more comprehensive and in-depth study of the mineral and material composition, as well as the improvement of existing technologies for the processing of this type of raw material become topical. Achieving this goal is complicated by the constant decline in the quality of ores involved in processing and requirement of $100 \%$ recycled water supply implementation. Based on the mineralogical, chemical, material composition, as well as technological research on the possibility of processing phosphate ores, it was concluded that the optimal scheme for the extraction of apatite is a flotation circuit with preliminary selective disintegration. At the same time, the possibility of extracting rare earth metals has been established.

Acknowledgements. The work is carried out under financial support of the Ministry of Education and Science of the Russian Federation, the project RFMEFI57417X0168.

\section{References}

Abdel-Moghny MW, Zhabin AV (2011) Mineralogical features of phosphate rocks Egypt. Bull Voronezh State Univ Ser Geol 2011(1):37-49

Abouzeid AM (2007) Upgrading of phosphate ores - a review. Powder Handling Process 19:92109

Aleksandrova TN, Litvinova NM, Gurman MA, Aleksandrov AV (2012) Comprehensive utilization of the far eastern apatite-containing raw materials. J Min Sci 48(6):1047-1053

Baioumy HM (2013) Effect of the depositional environment on the compositional variations among the phosphorite deposits in Egypt. Geol Geophys 54(4):589-600

Brylyakov YE (2004) The development of the theory and practice of complex enrichment of apatite-nepheline ores of the Khibinsky deposits

Evdokimova GA, Gershenkop ASh, Fokina NV (2012) The impact of bacteria of circulating water on apatite-nepheline ore flotation. J Environ Sci Health - Part A Toxic/Hazardous Subst Environ Eng 47(3):398-404

Gerasimova LG, Nikolaev AI, Maslova MV, Shchukina ES, Samburov GO, Yakovenchuk VN, Ivanyuk GY (2018) Titanite ores of the khibiny apatite-nepheline-deposits: selective mining, processing and application for titanosilicate synthesis. Minerals 8(10):446

Jasinski SM (2017) Phosphate Rock, U.S. Geological Survey, Mineral Commodity Summaries

Litvintsev VS, Melnikova TN, Yatlukova NG, Litvinova NM (2006) Mechanoactivation in the processes of ore preparation. Mt J (6):95-96 
Mitrofanova GV, Ivanova VA, Artemiev AV (2017) Use of reagents-flocculants in waterpreparation processes during phosphorous-containing ore processing. In: International multidisciplinary scientific GeoConference surveying geology and mining ecology management, SGEM 2017, vol 17, no 11, pp 1143-1150

Open Access This chapter is licensed under the terms of the Creative Commons Attribution 4.0 International License (http://creativecommons.org/licenses/by/4.0/), which permits use, sharing, adaptation, distribution and reproduction in any medium or format, as long as you give appropriate credit to the original author(s) and the source, provide a link to the Creative Commons license and indicate if changes were made.

The images or other third party material in this chapter are included in the chapter's Creative Commons license, unless indicated otherwise in a credit line to the material. If material is not included in the chapter's Creative Commons license and your intended use is not permitted by statutory regulation or exceeds the permitted use, you will need to obtain permission directly from the copyright holder. 